\title{
Thymic Tumor pT2 TNM Finding v8
}

National Cancer Institute

\section{Source}

National Cancer Institute. Thymic Tumor PT2 TNM Finding v8. NCI Thesaurus. Code C136311.

Thymic tumor with direct invasion of the pericardium (either partial or full thickness).

(from AJCC 8th Ed.) 